DOI: 10.20472/IAC.2018.039.015

ATULAN GUHA

Indian Institute of Management Kashipur, India

\title{
SECTORAL STRUCTURE OF INDIAN GROWTH: COULD KALDOR EXPLAIN IT?
}

\begin{abstract}
:
The GDP growth structure of India is dominated by the growth in service sector. Kaldor has argued that the sector that has the strongest capital accumulation and technical progress and input-output linkages with the rest of the economy should play the role of growth driver. Since, Indian sectoral growth structure is dominated by service sector it is expected that it should have the strongest backward and forward linkages with the rest of the economy and should have strongest capital accumulation and highest productivity growth. This paper argues through empirical evidences that service sector in India does not fulfil these criteria and hence, Kaldor's theory is inadequate to explain sectoral structure of the Indian growth.
\end{abstract}

\section{Keywords:}

Growth, Services, India, productivity

JEL Classification: 014, 053, 040 